\title{
Preface
}

\section{Security Sector Reform: An Essential Challenge for Peace Building Processes in Africa}

The articles in this publication emphasise the varying experience of security sector reform on the African continent. In the late 1990s, a peoplecentred human security perspective was introduced by Northern and Southern experts from academic centres, think-tanks, international organisations, governmental advocacy groups and nongovernmental organisations, who converged to consider the role of security forces in enforcing state and human security. This epistemic community has established links between the security system and society-at-large, focusing on threats to individuals' socioeconomic and political conditions, and on communal and personal safety. By supporting these networks, the UK has played a leading role in formalising the Security Sector Reform (SSR) concept, which was officially endorsed by the UK Department for International Development (DFID) in 1997. Thereafter, the Organisation for Economic Co-operation and Development's Development Assistance Committee (OECD-DAG) adopted a series of guidelines and political and operational principles relating to SSR.

The SSR concept refers to the set of policies, programmes and activities undertaken by a government, often supported by international partners and civil society constituencies, to improve the way in which security and justice are delivered, in accordance with human rights, democracy and transparency. The prospect of reducing conflicts and the presumed potential of SSR for reducing poverty have been the most significant arguments for donor agencies' engagement in SSR.

SSR extends beyond the narrow focus of traditional security assistance on defence, intelligence and policing, and strives to adopt a comprehensive and coordinated approach towards reforming various sectors of the security system (defence, police, justice, parliamentary and public security oversight, transparency in defence budgets, and respect for human rights in the exercise of functions): 'Security sector reform can be understood as an attempt to connect, in one concept, the opportunities of expanding development assistance into securityrelated fields and the challenges of new demands on development donors, and to provide both with a common vision. That vision is one of a security sector which promotes human development, helps to reduce poverty, and allows people including poor people - to expand their options in life'(Brzoska 2003).

SSR has emerged as one of the core activities for promoting peace and stability, especially - but not exclusively - in post-conflict or war-torn countries (Cawthra and Lukham 2003).

Understanding who provides security and justice is central to SSR. Although the SSR concept recognises that state security actors have a central role in justice and security provision, it states that effective security reform across the system requires working with a broad range of stakeholders including:

- Professional security providers: armed forces; police forces (including gendarmeries); paramilitary forces; national guards; presidential guards; intelligence services (both military and civilian); coast and border guards; customs services; and local security units (such as civil defence forces and vigilante groups).

- Management and oversight bodies: the executive; national security advisory bodies;

IDS Bulletin Volume 43 Number 4 July 2012 @ 2012 The Author. IDS Bulletin @ 2012 Institute of Development Studies Published by Blackwell Publishing Ltd, 9600 Garsington Road, Oxford OX4 2DQ, UK and 350 Main Street, Malden, MA 02148, USA 
legislative and select committees; ministries of defence, internal affairs and foreign affairs; financial management bodies (finance ministries, budget officers, financial audit and planning units); civil society organisations (civilian review boards, associations and NGOs); and public complaints commissions involved in security-related matters.

- Justice and rule of law actors: judiciary and justice ministries; prisons; criminal investigation and prosecution services; human rights commissions and ombudsmen; and customary and traditional justice systems.

- Non-statutory security forces: liberation armies; guerrilla armies; private security companies; and political party militias.

Reform programmes as promoted by SSR-related policies are two-fold. On the one hand, they aim to restructure the defence and security forces through the adoption of codes of conduct for the military and police forces; the revision of their status; the rationalisation of their organisation; the clarification of the sharing of responsibilities between the different defence and security services; improving the ethics of the armed and security forces; the development of a less coercive approach to law enforcement; the promotion of community policing; improving the judiciary skills of the judicial police services; and the clarification of the relationships between the judiciary police and the Ministry of Justice.

On the other hand, SSR programmes also aim to promote democratic control over the defence and security forces, making them more accountable

\section{References}

Brzoska, M. (2003) Development Donors and the Concept of Security Sector Reform, DCAF

Occasional Paper 4, Geneva: Centre for the Democratic Control of Armed Forces (DCAF)

Cawthra, G. and Luckham, R. (eds) (2003) Governing Insecurity: Democratic Control of Military and Security Establishments in Transitional Democracies, London and New York: Zed Books and responsive to oversight by the executive, legislative, judiciary and independent institutions (GFN-SSR 2007; OECD 2007; Mark 2010). To summarise, SSR seeks to increase security forces' abilities to meet the range of security needs, in a manner consistent with democratic norms and sound principles of governance, transparency and rule of law. This requires developing a holistic, comprehensive approach to SSR through/by coordinating reforms - both at national and international levels.

Africa is often considered the continent where SSR has great currency, even if some security reform processes have been initiated and framed in a number of African countries, without the SSR label and without any external intervention. However, there is great contrast in experiences across the continent. South Africa has been a pioneer of security sector reform and constitutes a unique example of an indigenously-driven process. The recent seizure of power by the military - or toppling of governments with their complicity - in several states (Mauritania, Guinea, Mali and Madagascar, and, to a lesser extent, Niger) can be seen as dramatic evidence of the lack of improvement in security governance in some parts of the continent.

SSR is often criticised for being a normative rather than an operational concept. In spite of repeated calls for an approach anchored in local peculiarities, SSR processes have, on the whole, tended to focus on technical aspects of reform. That is the reason why the SSR concept is often seen as an almost exclusively donor-driven concept.

GFN-SSR (2007) A Beginner's Guide to Security Sector Reform (SSR), University of Birmingham Mark, S. (ed.) (2010) The Future of Security Sector Reform, Ontario: Centre for International Governance Innovation OEGD (2007) The OECD-DAC Handbook on Security Sector Reform: Supporting Security and Justice, Paris: Organisation for Economic Co-operation and Development 